\title{
ANALISIS FRAUD DALAM PROSES AKADEMIK TERHADAP KUALITAS MAHASISWA AKUNTANSI
}

\section{FRAUD ANALYSIS IN THE ACADEMIC PROCESS ON THE QUALITY OF STUDENTS ACCOUNTING}

\author{
Devi Lestari Pramita Putri' ${ }^{1}$, Siti Salama Amar² \\ 1 Universitas Madura, Pamekasan \\ 2Universitas Madura, Pamekasan \\ Email : devi_permai@yahoo.co.id dan siti.salama@unira.ac.id
}

\begin{abstract}
ABSTRAK
Penelitian ini bertujuan untuk mengetahui perilaku yang mendatangkan keuntungan bagi mahasiswa secara tidak jujur termasuk didalamnya mencontek, plagiat, mencuri dan memalsukan sesuatu yang berhubungan dengan akademis. Jenis penelitian yang digunakan dalam penelitian ini adalah penelitian deskriptif kuantitatif yaitu penelitian yang dilakukan untuk mengetahui nilai variabel mandiri, baik suatu variabel atau lebih (indepeden) tanpa membuat perbandingan, atau menghubungkan dengan variabel yang lain. Jenis data yang digunakan adalah jenis data kuantitatif yang merupakan data yang terbentuk angka atau data kualitatif yang diangkakan. data kualitatif yang diangkakan (skoring) misalnya terdapat dalam skala pengukuran.. Sumber data yang digunakan adalah data primer yang diperoleh dari kuesioner. Teknik pengolahan dan analisis data menggunakan regresi inier berganda dengan hipotesis uji $f$ dan uji t pada variabel yang diteliti. Hasil penelitian menunjukkan bahwa variabel Pressure (X1) Opportunity (X2) dan Rationalization (X3) yang berpengaruh terhadap Kualitas Mahasiswa (Y). Serta yang dominan berpengaruh adalah Pressure (X1). Hasil penelitian dengan menggunakan $\mathrm{R}$ square dengan nilai 0,905 yang berarti bahwa Faktor Pressure memberikan pengaruh sebesar $90,5 \%$ terhadap kualitas mahasiswa dan sisanya $(100 \%-90,5 \%=9,5 \%)$ dipengaruhi oleh faktor lain yang tidak diteliti dalam penelitian ini.
\end{abstract}

Kata kunci: Pressure, Opportunity, Rationalization

\begin{abstract}
This study aims to determine the behavior that brings benefits to students dishonestly including cheating, plagiarism, stealing and falsifying something related to academia. This type of research used in this research is quantitative descriptive research that is research conducted to determine the value of an independent variable, either a variable or more (independent) without making comparisons, or connecting with other variables. The type of data used is the type of quantitative data which is data that is formed in numbers or qualitative data that is framed. Qualitative data that is framed (scoring) for example is in the measurement scale. The source of the data used is primary data obtained from the questionnaire. Data processing and analysis techniques using multiple linear regression with the ftest hypothesis and $t$ test on the variables studied. The results showed that the variable Pressure (X1) Opportunity (X2) and Rationalization (X3) had an effect on the quality of students $(Y)$. And the dominant influence is Pressure (X1). The results of the study using $R$ square with a value of 0.905 which means that the Pressure Factor gives an effect of $90.5 \%$ on the quality of students and the rest $(100 \%-90.5 \%=9.5 \%)$ is influenced by other factors not examined in this study.
\end{abstract}

Keywords: Pressure, Opportunity, Rationalization 


\section{PENDAHULUAN}

Pendidikan adalah suatu kekuatan yang sangat mempunyai pengaruh besar terhadap perkembangan fisik, mental, etika dan seluruh aspek kehidupan manusia. Fenomena yang cukup menarik di dalam pergururuan tinggi saat ini dan cukup mengancam dunia pendidikan akademis yaitu banyak ditemukannya praktik -praktik kecurangan (fraud) yang terjadi hal ini disebut academic fraud.

Kecurangan akademis didefinisikan sebagai bentuk perilaku yang mendatangkan keuntungan bagi mahasiswa secara tidak jujur termasuk didalamnya mencontek, plagiat, mencuri dan memalsukan sesuatu yang berhubungan dengan akademis. Perilaku kecurangan akademik didefinisikan sebagai upaya yang dilakukan mahasiswa untuk mendapatkan keberhasilan dengan cara yang tidak jujur dan dilakukan dengan sengaja. Perilaku tersebut meliputi beberapa bentuk perilaku seperti pelanggaran terhadap aturan dalam penyelesaian tugas dan ujian, memberikan keuntungan kepada mahasiswa lain dalam mengerjakan tugas atau ujian dengan cara yang tidak jujur dan pengurangan keakuratan yang diharapkan pada performasi mahasiswa.

Undang-Undang No. 12 tahun 2012 tentang Pendidikan Tinggi pasal 1 ayat 2 diuraikan bahwa pendidikan tinggi adalah jenjang pendidikan setelah pendidikan menengah yang mencakup progam diploma, progam sarjana, progam magister, progam doktor, dan progam profesi, serta progam spesialis, yang diselenggarakan oleh perguruan tinggi berdasarkan kebudayaan bangsa Indonesia. Pada pasal 3 bagian c disebutkan bahwa pendidikan tinggi berasaskan kejujuran. Untuk itu, seluruh civitas akademika harus menjunjung tinggi asas kejujuran dengan salah satu cara menghidari kecurangan akademik termasuk mahasiswa.

Penelitian mengenai kecurangan akademik dilakukan pada jurusan Akuntansi yang ada di Fakultas Ekonomi Universitas Madura. Seluruh civitas akademika yang ada di perguruan tinggi swasta di Madura harus menjunjung tinggi asas-asas yang termuat dalam Undang-Undang No. 12 tahun 2012 pasal 3 termasuk mahasiswa Fakultas Ekonomi Universitas Madura. Salah satu asas dalam pasal tersebut adalah asas kejujuran. Mahasiswa Fakultas Ekonomi harus menjunjung tinggi asas tersebut, karena mahasiswa Fakultas Ekonomi merupakan mahasiswa yang paling banyak berhubungan dengan perhitungan keuangan baik dalam lingkup bank, instansi, maupun negara. Lulusan Fakultas Ekonomi Universitas Madura diharapkan dapat menjadi pegawai bank, akuntan perusahan, maupun menteri perekonomian bagi jurusan non kependidikan, dan menjadi guru bagi jurusan kependidikan yang akan mendidik generasi penerus bangsa. Sehingga berdampak negatif apabila karakter mahasiswa yang dihasilkan dari lulusan ini tidak baik, yaitu akan merugikan tempat kerja dan negara.

Banyak faktor yang mempengaruhi mahasiswa melakukan kecurangan akademik. Tidak jarang mahasiswa mendapatkan tekanan dari pihak luar untuk memperoleh nilai yang baik dalam ujian. Tekanan yang dimaksudkan dapat datang dari orang terdekatnya seperti orang tua, saudara, atau teman-temannya (Hartanto, 2012: 1). Tidak hanya dari pihak eksternal, tekanan juga bisa berasal dari pihak internal mahasiswa. Pada akhirnya, dari tekanan tersebut dapat membentuk mahasiswa yang mempunyai keyakinan bahwa nilai adalah segalanya, sehingga mahasiswa akan melakukan berbagai macam cara agar mendapatkan nilai yang bagus dan mencapai target. Tidak sedikit mahasiswa yang menggunakan cara-cara yang melanggar peraturan yaitu dengan melakukan kecurangan akademik (Albrecht, dkk., 2012: 31). Dalam Tuanakotta (2010: 205) Donald R.Cressey menyebutkan secara umum penyebab terjadinya kecurangan yaitu tekanan, kesempatan, dan rasionalisasi atau yang biasa disebut dengan Fraud Triangle. Pressure (tekanan), yaitu 
adanya insentif/ tekanan/ kebutuhan untuk melakukan fraud, opportunity(kesempatan), yaitu situasi yang membuka kesempatan untuk memungkinkan suatu kecurangan terjadi, rationalization (rasionalisasi) yaitu mencari pembenaran sebelum melakukan kejahatan, bukan sesudahnya. Hal ini yang menjadikan peneliti merasa tertarik untuk melakukan penelitian dengan judul "Analisis Fraud Triangle Dalam Proses Akademik Terhadap Kualitas Mahasiswa Pada Fakultas Ekonomi Di Universitas Madura". Berdasarkan uraian pendahuluan diatas, maka perumusan masalah dalam penelitian ini adalah, 1) Bagaimana pengaruh tekanan dalam proses akademik terhadap kualitas mahasiswa Fakultas Ekonomi Universitas Madura, 2) Bagaimana pengaruh kesempatan dalam proses akademikterhadap kualitas mahasiswa Fakultas Ekonomi Universitas Madura, 3) Bagaimana pengaruh rasionalisasi dalam proses akademikterhadap kualitas mahasiswa Fakultas Ekonomi Universitas Madura ? Berdasarkan rumusan masalah tersebut, maka tujuan dari penelitian ini adalah, 1) Untuk menguji pengaruh tekanan dalam proses akademik terhadap kualitas mahasiswa Fakultas Ekonomi Universitas Madura, 2) Untuk menguji pengaruh kesempatan dalam proses akademik terhadap kualitas mahasiswa Fakultas Ekonomi Universitas Madura, 3) Untuk menguji rasionalisasi dalam proses akademik terhadap kualitas mahasiswa Fakultas Ekonomi Universitas Madura.

\section{LANDASAN TEORI}

\section{Pressure(Tekanan)}

Pressure (tekanan), yaitu adanya insentif/tekanan/kebutuhan untuk melakukan Fraud. Tekanan dapat mencakup hampir semua hal termasuk gaya hidup, tuntutan ekonomi, dan lain-lain termasuk hal keuangan dan non keuangan. Faktor non keuangan tersebut meliputi; kedudukan, kegagalan pribadi, kegagalan bisnis, keterpurukan dalam kesendirian, kebiasaan buruk, dan kekesalan/ kebencian (Tuanakotta, 2010:207). Albrecht (2012) menjelaskan bahwa tekanan (pressure/pressure) merupakan suatu situasi dimana seseorang merasa perlu untuk melakukan kecurangan. Semakin tingginya pressure maka semakin besar pula kemungkinan perilaku kecurangan akademik akan terjadi. Tekanan dalam penelitian yang akan dilakukan ini merupakan tekanan yang dialami oleh mahasiswa sebagai faktor pendorong bagi mahasiswa untuk melakukan kecurangan akademik. Jadi tekanan dalam konteks kecurangan akademik merupakan dorongan maupun motivasi yang dihadapi mahasiswa dalam kesehariannya yang mempunyai hubungan dengan masalah akademik dan menyebabkan mereka memiliki tekanan yang kuat untuk mendapatkan hasil akademik yang terbaik dengan cara apapun.

Tekanan merupakan dorongan/motivasi yang dirasakan dalam diri seseorang baik berasal dari pihak internal (diri sendiri) maupun pihak eksternal (lingkungan) sehingga menyebabkan seseorang terpaksa melakukan suatu tindakan. Tindakan yang didasari oleh keterpaksaan biasanya tidak memperhatikan baik buruknya suatu tindakan tersebut. Salah satu tindakan yang didasari oleh tekanan yaitu perilaku kecurangan. Setiap pelaku kecurangan menghadapi beberapa jenis tekanan yang dirasakan (Zimbelman dkk, 2014:354).

Tekanan merupakan tipe tekanan yang paling umum untuk melakukan kecurangan. Biasannya, ketika kecurangan manajemen terjadi, perusahaan memperbesar nilai aset pada laporan posisi keuangan dan laba bersih pada laporan laba rugi komprehensif. Mereka biasannya memiliki tekanan untuk melakukannya karena posisi kas yang tidak menguntungkan, piutang tak tertagih, kehilangan pelanggan,persediaan yang usang, penurunan pasar, atau pembatasan kesepakatan pinjaman yang dilanggar (Mark F. Zimbelman, Conan C. Albrecht, W. Steve Albrecht, Chad O. Albrecht, 2014-357). 


\section{Indikator Tekanan Akademik}

Berdasarkan beberapa teori yang telah diuraikan mengenai tekanan akademik, peneliti menyimpulkan untuk menggunakan beberapa indikator guna mengukur seberapa besar tekanan yang dimiliki oleh mahasiswa yang pada akhirnya akan mempengaruhi tinggi rendahnya perilaku kecurangan akademik. Indikatornya antara lain :

1. Peringkat akademik mahasiswa.

2. Kegagalan akademik mahasiswa.

3. Persaingan akademik antar mahasiswa.

4. Ketidakpuasan akademik pada mahasiswa. (Albrecht,dkk., 2012: 36)

Berdasarkan teori triangle tidak hanya tekanan saja yang mempengaruhi terjadikan tindakan kecurangan, melainkan terdapat faktor kesempatan berbuat kecurangan. Pada kecurangan yang terjadi dalam proses pembelajaran di perguruan tinggi juga akan dipengaruhi oleh faktor kesempatan berbuat kecurangan.

\section{Pengertian Opportunity (Kesempatan)}

Opportunity (kesempatan), yaitu situasi yang membuka kesempatan untuk memungkinkan suatu kecurangan terjadi. Biasanya terjadi karenapengendalian internal perusahaan yang lemah, kurangnya pengawasan dan penyalahgunaan wewenang (Tuanakotta, 2010: 211).

Kesempatan biasanya timbul karena adanya sistem yang kurang bagus. Sehingga pada dasarnya kesempatan merupakan faktor yang paling mudah untuk diminimalisasi dan diantisipasi, ketika sudah tercipta sistem yang baik dan pengendaliannya bagus semakin kecil kesempatan orang untuk melakukan tindakan kecurangan. Becker et al. dalam penelitiannya mendapati bahwa kesempatan merupakan faktor yang mendorong terjadinya kecurangan akademik. Kesempatan akan berpengaruh secara positif terhadap perilaku kecuranngan, dimana semakin besar kesempatan yang tersedia bagi seseorang untuk me lakukan kecurangan maka akan semakin besar pula kemungkinan orang tersebut untuk melakukan kecurangan. Hal ini berarti opportunity mempunyai pengaruh positif terhadap perilaku kecurangan akademik mahasiswa akuntansi. Kesempatan merupakan tindakan untuk melakukan kecurangan, menyembunyikannya, atau untuk menghindari adanya sanksi tegas dari elemen kedua dari segitiga kecurangan (Mark F. Zimbelman, Conan C. Albrecht, W. Steve Albrecht, Chad O. Albrecht, 2014-360).

\section{Indikator Kesempatan Berbuat Kecurangan Akademik}

Berdasarkan teori yang telah dijelaskan di atas mengenai kesempatan berbuat kecurangan, adapun yang dijadikan indikator dalam kesempatan berbuat kecurangan adalah :

a) Kurangnya pengendalian untuk mencegah dan mendeteksi pelanggaran.

b) Ketidakmampuan untuk menilai kualitas dari suatu hasil.

c) Kegagalan dalam mendisiplinkan pelaku kecurangan.

d) Kurangnya akses informasi.

e) Ketidaktahuan, apatis atau ketidakpedulian, dan kemampuan yang tidak memadai dari pihak yang dirugikan.

f) Kurangnya pemeriksaan. (Albrecht, dkk., 2012: 39) 


\section{Rasionalisasi}

Rationalization (rasionalisasi) yaitu mencari pembenaran sebelum melakukan kejahatan, bukan sesudahnya. Rasionalisasi diperlukan untuk melawan hukum demi mempertahankan jati diri pelaku kecurangan (Tuanakotta 2010: 205).

Albrecht, dkk., (2012:49) berpendapat bahwa rasionalisasi merupakan pembenaran diri atau alasan yang salah untuk suatu perilaku yang salah. Dengan adanya rationalization dari mahasiswa akuntansi melakukan kecurangan, maka semakin besar kemungkinan perilaku kecurangan akademik akan terjadi. Rasionalisasi dapat diartikan sebagai suatu sikap atau anggapan pribadi bahwa kecurangan merupakan tindakan yang tidak salah. Dalam Kamus Besar Bahasa Indonesia (KBBI) mendefinisikan rasionalisasi sebagai proses atau cara untuk menjadikan sesuatu yang tidak rasional menjadi rasional (dapat diterima akal sehat) atau menjadi sesuatu yang baik. Berdasarkan pengertian di atas rasionalisasi dalam tindakan kecurangan akademik merupakan sebuah perilaku pembenaran diri yang dilakukan oleh mahasiswa untuk mengurangi rasa bersalah yang timbul karena telah melakukan perbuatan yang tidak jujur dalam konteks akademik.

Menurut cressey, rasionalisasi (rationalization) terjadi karena sebagian besar pelaku merasa dirinya tidak melakukan tindak kriminal, tetapi melakukan sesuatu yang sudah sewajarnya mereka melakukan. Rasionalisasi diperlukan oleh para pelaku fraud untuk menciptakan persepsi bahwa mereka adalah orang yang jujur dan dapat dipercaya (Subagio Tjahjono, SE, CFE, CIA, CISA, Josua Tarigan, SE, MBA, CFP, CMA, CSRS, Dr.H. Budi Untung , SH, CN, MM, Jap Efendi, Phd, Yohana Hardjanti, SE, CMA, AK, 2013-31).

\section{Indikator Rasionalisasi Berbuat Kecurangan Akademik}

Berdasarkan teori yang telah dijelaskan di atas mengenai rasionalisasi berbuat kecurangan, adapun yang dijadikan indikator dalam rasionalisasi berbuat kecurangan adalah:

1. Kecurangan sering dilakukan.

2. Pelaku melakukan kecurangan hanya ketika dalam keadaan terdesak.

3. Perlakuan tidak adil dari kampus.

4. Tidak ada pihak yang dirugikan.

5. Hasil kecurangan untuk menjaga nama baik orang tua dan dirinya.

(Albrecht, dkk., 2012: 49)

\section{Pengertian Kecurangan Akademik}

Kecurangan berasal dari kata "curang" yang dalam Kamus Besar Bahasa Indonesia, curang memiliki arti berlaku tidak jujur. Menurut Albrecht, dkk., (2012: 6), kecurangan adalah istilah umum yang mencakup semua cara dimana kelicikan digunakan oleh seseorang untuk melakukan sesuatu demi mendapatkan keuntungan lebih dari yang lain dari penilaian yang salah.

Menurut Cizek (2003) dalam Annisa (2009: 16) kecurangan dapat diartikan sebagai perilaku yang dilakukan oleh mahasiswa dengan sengaja meliputi: (1) pelanggaran terhadap peraturan-peraturan dalam menyelesaikan ujian atau tugas, (2) memberikan keuntungan kepada mahasiswa lain di dalam ujian atau tugas dengan cara yang tidak jujur, (3) pengurangan keakuratan yang diharapkan pada performansi mahasiswa. Kecurangan akademis didefinisikan sebagai bentuk perilaku yang mendatangkan keuntungan bagi mahasiswa secara tidak jujur termasuk didalamnya mencontek, plagiat, mencuri dan memalsukan sesuatu yang berhubungan dengan akademis (Hendricks, 2004 dalam Siti Annisa, 2009: 17). 


\section{Bentuk-Bentuk Kecurangan Akademik}

Tindakan-tindakan curang di dalam perguruan tinggi mencakup aktivitas di perkuliahan di kelas, aktivitas ujian, tugas-tugas perkuliahan, hubungan dosen dengan mahasiswa, dan hubungan antar mahasiswa dalam hal kegiatan akademik. Tindakan curang tidak selalu merupakan hal-hal yang sudah diatur secara eksplisit dalam undang-undang sehingga mempunyai kekuatan secara hukum ataupun dalam peraturan akademik yang ditetapkan perguruan tinggi. Seperti halnya dalam banyak tataran etika lain juga terjadi bahwa banyak juga nilai-nilai etis yang tidak dapat dijabarkan dalam sebuah peraturan atau undangundang, karena sifat judgmental yang menyertai nilai tersebut. Meskipun pada umumnya perguruan tinggi menetapkan secara umum bahwa lingkungan akademik yang ditegakkan didasarkan pada nilai-nilai kejujuran, loyalitas, toleransi, tanggung jawab,keadilan, dan lainlain, namun tidak selalu secara rinci dan tegas nilai-nilai tersebut dijabarkan dalam tindakan mana yang salah dan yang benar.

Menurut Hendrick (2004) dalam Annisa (2009: 21) bentuk-bentuk kecurangan akademis yang terjadi pada mahasiswa adalah:

1) Penggunaan catatan pada saat ujian.

2) Menyalin jawaban orang lain ketika ujian.

3) Menggunakan metode-metode yang tidak jujur untuk mengetahui apa yang akan diujikan.

4) Menyalin jawaban ujian dari orang lain tanpa sepengetahuan orang tersebut.

5) Membantu orang lain untuk berlaku curang.

6) Berlaku curang dengan berbagai cara.

7) Menyalin tugas karya ilmiah orang lain dan mengakuinya sebagai pekerjaan sendiri.

8) Memalsukan daftar pustaka.

9) Melakukan kerja sama dengan pengajar untuk menyelesaikan tugas individu.

10) Menyalin beberapa kalimat (termasuk dari internet) tanpa memasukkan keterangan ke dalam daftar pustaka.

11) Membeli karya ilmiah dari orang lain.

\section{Indikator Kecurangan Akademik}

Berdasarkan teori yang telah dijelaskan di atas, terdapat dua jenis indikator perilaku kecurangan akademik, diantaranya :

1. Perilaku kecurangan akademik ketika pengerjaan tugas individu, meliputi beberapa kegiatan seperti;

a. Menyalin tugas orang lain.

b. Plagiatime (mengutip tanpa memasukan keterangan ke dalam daftar pustaka).

c. Membeli karya ilmiah (tugas) orang lain.

2. Perilaku kecurangan akademik ketika pengerjaan tugas kelompok.

a. Menyalin tugas kelompok lain.

b. Plagiatime (mengutip tanpa memasukan keterangan ke dalam daftar pustaka).

c. Membeli karya ilmiah (tugas) kelompok lain.

3. Perilaku kecurangan akademik ketika Ujian Tengah Semester (UTS) dan Ujian Akhir Semester (UAS)

a. Membuat catatan untuk digunakan menyontek saat ujian. 


\section{b. Menyalin jawaban orang lain.}

c. Membantu orang lain berlaku curang. Hendrick (2004) dalam Annisa (2009: 21)

Berdasarkan teori fraud triangle kecurangan dipengaruhi oleh tiga elemen antara lain; tekanan, kesempatan, dan rasionalisasi untuk berbuat kecurangan. Mahasiswa sebagai subjek dalam proses pembelajaran di perguruantinggi juga memiliki beberapa faktor yang menyebabkan terjadinya kecurangan akademik.

\section{Hipotesis}

Hipotesis merupakan jawaban sementara terhadap rumusan masalah penelitian. Dikatakan sementara, karena jawaban yang akan diberikan baru didasarkan pada teori yang relevan, belum didasarkan pada fakta-fakta empiris yang diperoleh melalui pengumpulan data. Jadi hipotesis juga dinyatakan sebagai jawaban teoritis terhadap rumusan masalah penelitian, belum jawaban empirik. (Sugiyono, 2012:64)

Berdasarkan rumusan masalah, penelitian terdahulu dan landasan teori yang telah peneliti lakukan diawal, hipotesis dalam penelitian ini berbentuk hipotesis asosiatif. Berikut merupakan hipotesis penelitian yang peneliti buat dalam penelitian ini:

Ha1: Tekanan berpengaruh positif pada kualitas mahasiswa

$\mathrm{Ha}_{2}$ : Kesempatan berpengaruh positif pada kualitas mahasiswa

Наз: Rasionalisasi berpengaruh positif pada kualitas mahasiswa

Ha4:Tekanan (x1), Kesempatan (x2), Rasionalisasi (x3), berpengaruh positif pada kualitas mahasiswa $(\mathrm{y})$

\section{METODOLOGI PENELITIAN}

\section{Jenis dan Sumber Data Penelitian}

Jenis data yang digunakan dalam penelitian ini adalah data primer yaitu sumber data yang diperoleh langsung dari lokasi peneliti dengan memberikan data kepada pengumpul data (Sugiyono, 2012;156). Dalam penelitian ini digunakan data primer yaitu kuesioner yang diberikan kepada mahasiswa akuntansi di Universitas Madura Populasi dalam penelitian ini adalah mahasiswa akuntansi fakultas ekonomi Universitas Madura yang berjumlah 262 mahasiswa prodi akuntansi. Sampel dalam penelitian ini berjumlah 129 mahasiswa akuntansi, dengan menggunakan Purposive Sampling, dimana teknik pengambilan sampel dilakukan dengan pertimbangan tertentu dengan tujuan untuk memberikan informasi yang maksimal. Kriteria yang ditetapkan oleh peneliti sebagai berikut:

1. Merupakan mahasiswa Fakultas Ekonomi Prodi Akuntansi.

2. Mahasiswa Prodi Akuntansi yang sudah menempuh Mata Kuliah Auditor.

Tabel

Penentuan Sampel Penelitian

\begin{tabular}{|c|l|c|}
\hline No & \multicolumn{1}{|c|}{ Kriteria } & Jumlah \\
\hline 1 & Mahasiswa Prodi Akuntansi & 262 \\
\hline 2 & $\begin{array}{l}\text { Mahasiswa Prodi Akuntansi yang belum menempuh mata } \\
\text { kuliah Auditor }\end{array}$ & (133) \\
\hline
\end{tabular}


\begin{tabular}{|l|l|c|}
3 & $\begin{array}{l}\text { Mahasiswa Prodi Akuntansi yang sudah menempuh mata } \\
\text { kuliah Auditor }\end{array}$ & 129 \\
\hline
\end{tabular}

Metode Analisis dan Hipotesis Penelitian

Pengujian pertama dengan uji statistik deskriptif, kemudian pengujian asumsi klasik sebagai salah satu syarat untuk bisa menggunakan persamaan regresi berganda adalah terpenuhinya asumsi klasik. Empat uji asumsi klasik dalam penelitian ini meliputi normalitas, linearitas, multikolinearitas dan heteroskedastisitas.

\section{Operasional Variabel Penelitian}

Pressure (tekanan) (X1)

Pressure (tekanan), yaitu adanya insentif/ tekanan/ kebutuhan untuk melakukan Fraud. Tekanan dapat mencakup hampir semua hal termasuk gaya hidup, tuntutan ekonomi, dan lain-lain termasuk hal keuangan dan non keuangan (Tuanakotta,2010:207). Tekanan merupakan situasi dimana seseorang perlu merasa memilih untuk melakukan perilaku kecurangan dengan adanya tekanan perilaku kecurangan dapat datang dari orang-orang terdekat seperti orang tua, saudara, atau teman-temannya.

Peneliti menyimpulkan untuk menggunakan beberapa indikator guna mengukur seberapa besar tekanan yang dimiliki oleh mahasiswa yang pada akhirnya akan mempengaruhi tinggi rendahnya perilaku kecurangan akademik. Indikatornya antara lain :

1. Peringkat akademik mahasiswa.

2. Kegagalan akademik mahasiswa.

3. Persaingan akademik antar mahasiswa.

4. Ketidakpuasan akademik pada mahasiswa.

Pertanyaan dalam kuesioner tersebut ditujukan untuk meneliti independensi,kecurangan akademik dan faktor-faktor mahasiswa melakukan kecurangan akademik berupa tekanan yang digunakan sebagai indikator dalam pengukuran variabel pressure (tekanan) pada Universitas Madura fakultas ekonomi jurusan akuntansi. Dalam melakukan pengukuran variabel pressure (tekanan) pada Universitas Madurafakultas ekonomi jurusan akuntansi akan digunakan skala pengukuran yaitu skala likert 4 (empat) pointdengan rincian sebagai berikut: (1) Sangat Setuju, (2) Setuju, (3) Tidak Setuju, (4) Sangat Tidak Setuju.

\section{Opportunity (kesempatan) (X2)}

Opportunity (kesempatan), yaitu situasi yang membuka kesempatan atau celah untuk melakukan suatu kecurangan. Semakin meningkatnya opportunity yang didapat, maka semakin besar pula kemungkinan perilaku kecurangan akademik. Kesempatan biasanya timbul karena adanya sistem yang kurang bagus. Sehingga pada dasarnya kesempatan merupakan faktor yang paling mudah untukdiminimalisasi dan diantisipasi, ketika sudah tercipta sistem yang baik dan pengendaliannya bagus semakin kecil kesempatan orang untuk melakukan tindakan kecurangan.

Peneliti menyimpulkan untuk menggunakan beberapa indikator guna mengukur seberapa besar kesempatan yang dimiliki oleh mahasiswa yang pada akhirnya akan mempengaruhi tinggi rendahnya perilaku kecurangan akademik. Indikatornya antara lain :

1. Kurangnya pengendalian untuk mencegah dan mendeteksi pelanggaran.

2. Ketidakmampuan untuk menilai kualitas dari suatu hasil.

3. Kegagalan dalam mendisiplinkan pelaku kecurangan. 
4. Kurangnya akses informasi.

5. Ketidaktahuan, apatis atau ketidakpedulian dan kemampuan yang tidak memadai dari pihak yang dirugikan.

6. Kurangnya pemeriksaan.

Pertanyaan dalam kuesioner tersebut ditujukan untuk meneliti independensi,kecurangan akademik dan faktor-faktor mahasiswa melakukan kecurangan akademik berupa kesempatan yang digunakan sebagai indikator dalam pengukuran variabel opportunity (kesempatan) pada Universitas Madura fakultas ekonomi jurusan akuntansi. Dalam melakukan pengukuran variabel opportunity (kesempatan) pada Universitas Madura fakultas ekonomi jurusan akuntansi akan digunakan skala pengukuran yaitu skala likert 4 (empat) pointdengan rincian sebagai berikut: (1) Sangat Setuju, (2) Setuju, (3) Tidak Setuju, (4) Sangat Tidak Setuju.

\section{Rationalization (rasionalisasi) (X3)}

Rationalization (rasionalisasi) yaitu mencari pembenaran sebelum melakukan kejahatan, bukan sesudahnya. Rasionalisasi diperlukan untuk melawan hukum demi mempertahankan jati diri pelaku kecurangan (Tuanakotta 2010:205). Albrecht, dkk., (2012:49). Rasionalisasi merupakan suatu sikap pembenaran diri atau alasan yang salah untuk suatu perilaku yang salah. Dengan adanya rationalization dari mahasiswa akuntansi melakukan kecurangan, maka semakin besar potensi perilaku kecurangan akademik akan terjadi.

Peneliti menyimpulkan untuk menggunakan beberapa indikator guna mengukur seberapa besar rasionalisasi yang dimiliki oleh mahasiswa yang pada akhirnya akan mempengaruhi tinggi rendahnya perilaku kecurangan akademik. Indikatornya antara lain :

1. Kecurangan sering dilakukan.

2. Pelaku melakukan kecurangan hanya ketika dalam keadaan terdesak.

3. Perlakuan tidak adil dari kampus.

4. Tidak ada pihak yang dirugikan.

5. Hasil kecurangan untuk menjaga nama baik orang tua dan dirinya.

Pertanyaan dalam kuesioner tersebut ditujukan untuk meneliti independensi,kecurangan akademik dan faktor-faktor mahasiswa melakukan kecurangan akademik berupa rasionalisasi yang digunakan sebagai indikator dalam pengukuran variabel Rationalization (rasionalisasi) pada Universitas Madura fakultas ekonomi jurusan akuntansi. Dalam melakukan pengukuran variabel Rationalization (rasionalisasi) pada Universitas Madura fakultas ekonomi jurusan akuntansi akan digunakan skala pengukuran yaitu skala likert4 (empat) pointdengan rincian sebagai berikut: (1) Sangat Setuju, (2) Setuju, (3) Tidak Setuju, (4) Sangat Tidak Setuju.

\section{Kualitas Mahasiswa (Y)}

Kualitas mahasiswa adalah seseorang dari perguruan tinggi yang lulus setelah menempuh pendidikan dan memiliki nilai kesesuaian untuk menjadi seorang tenaga kerja yang profesional. Peneliti menyimpulkan untuk menggunakan beberapa indikator guna mengukur seberapa besar kualitas mahasiswa yang dimiliki oleh mahasiswa yang pada akhirnya akan mempengaruhi tinggi rendahnya perilaku kecurangan akademik. Indikatornya antara lain :

1. Kecerdasan mahasiswa

2. Adanya rasa ego yang tinggi pada mahasiswa

3. Adanya unsur paksaan dari pihak luar

4. kebohongan

Pertanyaan dalam kuesioner tersebut ditujukan untuk meneliti independensi,kecurangan akademik dan faktor-faktor mahasiswa melakukan kecurangan akademik berupa rasionalisasi 
yang digunakan sebagai indikator dalam pengukuran variabel Kualitas Mahasiswa pada Universitas Madura fakultas ekonomi jurusan akuntansi. Dalam melakukan pengukuran variabel Kualitas Mahasiswa pada Universitas Madurafakultas ekonomi jurusan akuntansi akan digunakan skala pengukuran yaitu skala likert4 (empat) pointdengan rincian sebagai berikut: (1) Sangat Setuju, (2) Setuju, (3) Tidak Setuju, (4) Sangat Tidak Setuju.

\section{HASIL DAN PEMBAHASAN}

\section{Hasil Penelitian}

Peneliti telah menyebarkan kuesioner sebanyak 129 ke responden yaitu 64 mahasiswa akuntansi semester 6 dan 65 mahasiswa akuntansi semester 8 Fakultas Ekonomi Universitas Madura.

\section{Hasil Analisis Regresi Berganda}

Analisis regresi berganda adalah metode statistik untuk menguji pengaruh antara satu variabel terikat dengan lebih dari satu variabel bebas (Gozali, 2013:7). Menurut Gujarati (2003) dalam Ghozali (2013:95) analisis regresi pada dasarnya adalah studi mengenai ketergantungan variabel dependen (terikat) dengan satu atau lebih variabel independen (penjelas/ bebas), dengan tujuan untuk mengestimasi dan/ atau memprediksi rata-rata populasi atau nilai rata-rata variabeldependen berdasarkan nilai variabel independen yang diketahui. Analisis regresi berganda digunakan untuk mengetahui seberapa besar pengaruh tekanan akademik (X1), kesempatan berbuat kecurangan (X2), dan rasionalisasi berbuat kecurangan (X3) terhadap kualitas mahasiswa $(\mathrm{Y})$. Berikut hasil analisis regresi berganda untuk data penelitian ini yang diolah dengan bantuan progam SPSS v. 21 yang disajikan dalam tabel

\section{Tabel Hasil Analisis Regresi Berganda}

Coefficients ${ }^{\mathrm{a}}$

\begin{tabular}{|l|c|c|c|c|c|}
\hline \multirow{2}{*}{ Model } & \multicolumn{2}{|c|}{$\begin{array}{c}\text { Unstandardized } \\
\text { Coefficients }\end{array}$} & $\begin{array}{c}\text { Standardized } \\
\text { Coefficients }\end{array}$ & \multirow{2}{*}{ T } & \multirow{2}{*}{ Sig } \\
\cline { 2 - 4 } & B & Std.Error & Beta & & 0,014 \\
\hline 1 (Constant) & 0,293 & 0,118 & & 2,485 & 0,018 \\
X1 Pressure & 0,459 & 0,052 & 0,463 & 8,806 & 0,000 \\
X2 Opportunity & 0,371 & 0,049 & 0,333 & 7,542 & 0,000 \\
X3 Rationalization & 0,313 & 0,042 & 0,275 & 7,361 & 0,000 \\
\hline
\end{tabular}

Sumber: Data penelitian, diolah 2019

Berdasarkan hasil analisis regresi berganda pada tabel 4.1.3.5. di atas diperoleh koefisien untuk variabel bebas yaitu $X 1=0,459, X 2=0,371, \quad X 3=0,313$, dengan konstanta sebesar 0,293 . Dengan demikian, dapat dihasilkan persamaan regresi berganda, sebagai berikut:

$$
Y=0,293+0,459 \times 1+0,371 \times 2+0,313 \times 3+e
$$




\section{Pembahasan}

\section{Pengaruh Positif Signifikan Tekanan Akademik, Kesempatan Berbuat Kecurangan, dan Rasionalisasi Berbuat Kecurangan secara Simultan terhadap Kualitas Mahasiswa}

Menurut Albrecht, dkk (2012) tekanan merupakan situasi dimana seseorang merasa perlu memilih melakukan perilaku kecurangan. Kesempatan berbuat kecurangan adalah situasi dimana seseorang merasa memiliki kombinasi situasi dan kondisi yang memungkinkan dalam melakukan kecurangan akademik dan tidak terdeteksi. Sedangkan rasionalisasi berbuat kecurangan adalah pembenaran diri atau alasan yang salah untuk suatu perilaku yang salah. Kecurangan adalah mencakup semua cara dimana kelicikan digunakan oleh seseorang untuk melakukan sesuatu demi mendapakan keuntungan lebih dari yang lain dari penilaian yang salah.

Uji simultan (uji F) pada hasil penelitian menunjukkan bahwa tekanan akademik, kesempatan berbuat kecurangan, dan rasionalisasi berbuat kecurangan berpengaruh positif terhadap kecurangan akademik sehingga H1diterima. Selain itu, hasil uji determinasi simultan menunjukkan bahwa 90,5\% variabel kecurangan akademik mampu dijelaskan oleh variasi variabel independen, yakni tekanan akademik, kesempatan berbuat kecurangan, dan rasionalisasi berbuat kecurangan.

Hal ini bermakna bahwa konsep fraud triangle yang mencakup tekanan, kecurangan, dan rasionalisasi akan memberikan dampak terhadap kecurangan akademik pada mahasiswa.

Penelitian ini sejalan dengan penelitian yang dilakukan oleh Muhammad Hadi Santoso (2014) yang menyebutkan bahwa tekanan akademik, kesempatan berbuat kecurangan, dan rasionalisasi berbuat kecurangan berpengaruh signifikan terhadap kecurangan akademik. Begitu pula dengan penelitian yang dilakukan oleh Becker (2006) dalam Santoso (2014) juga menyebutkan terdapat pengaruh signifikan ketiga variabel tersebut berpengaruh positif signifikan terhadap kecurangan akademik.

Pengaruh tekanan akademik, kesempatan berbuat kecurangan, dan rasionalisasi berbuat kecurangan terhadap kecurangan akademik pada mahasiswa Fakultas Ekonomi Universitas Madura menunjukkan kesesuaian dengan teori fraud triangle menurut Donald R.Cressey dalam Tuanakotta (2010: 205). Teori ini menyebutkan bahwa terdapat tiga elemen penyebab terjadinya kecurangan yang disebut dengan triangle yakni tekanan, kesempatan dan rasionalisasi.

\section{Pengaruh Tekanan Akademik terhadap Kualitas Mahasiswa}

Menurut Albrecht, dkk (2012: 31) tekanan merupakan situasi dimana seseorang merasa perlu memilih melakukan perilaku kecurangan. Sedangkan menurut Hartanto (2012: 1) Tekanan dapat datang dari orang-orang terdekatnya seperti orang tua, saudara, atau teman-temannya. Jadi, tekanan adalah kondisi dari dalam maupun lingkungan sekitar yang memaksa seseorang melakukan kecurangan untuk memperoleh tujuan terbaik karena banyaknya tugas atau tuntutan yang dibebankan pada dirinya.

Uji parsial ( $\mathrm{t}$ ) pada hasil penelitian menunjukkan terdapat pengaruh pengaruh positif signifikan tekanan akademik terhadap kecurangan akademik mahasiswa Fakultas Ekonomi Universitas Madura sehingga hipotesis $2(\mathrm{H} 2)$ diterima. Penelitian ini sejalan dengan Muhammad Hadi Santoso (2014) yang menyebutkan bahwa terdapat pengaruh signifikan tekanan terhadap perilaku kecurangan akademik. Hasil penelitian tersebut menjelaskan bahwa 
terdapat tiga item yang mahasiswa rasakan yaitu; dosen memberikan nilai secara adil, mahasiswa harus mendapatkan nilai bagus bagaimanapun caranya, dan mahasiswaharus mempertahankan IP (Indeks Prestasi). Dari ketiga item tersebut dijelaskan bahwa tekanan merupakan salah satu pemicu timbulnya kecurangan akademik yang dilakukan mahasiswa.

Hasil penelitian ini sejalan juga dengan teori yang dikemukakan oleh Albrecht, dkk (2012:33) bahwa tekanan akademik berpengaruh terhadap tinggi rendahnya perilaku kecurangan. Orang yang merasa tertekan karena berbagai beban yang dimiliki akan melakukan hal-hal yang cenderung mengabaikan aturan yang ada sehingga mendorong orang tersebut melakukan kecurangan.

\section{Pengaruh Kesempatan Berbuat Kecurangan terhadap Kualitas Mahasiswa}

Menurut Albrecht, dkk., (2012: 31) berpendapat bahwa kesempatan merupakan situsi dimana seseorang merasa memiliki kombinasi situasi dankondisi yang memungkinkan dalam melakukan kecurangan akademik dan tidak terdeteksi. Opportunity (kesempatan), yaitu situasi yang membuka kesempatan untuk memungkinkan suatu kecurangan terjadi. Biasanya terjadi karena pengendalian internal perusahaan yang lemah, kurangnya pengawasan dan penyalahgunaan wewenang (Tuanakotta, 2010: 211). Jadi, kesempatan berbuat kecurangan akademik adalah kombinasi waktu dan situasi (peluang) yang dimiliki oleh seseorang untuk melakukan kecurangan akademik.

Uji parsial ( $t$ ) pada hasil penelitian menunjukkan terdapat pengaruh pengaruh positif signifikan kesempatan berbuat kecurangan terhadap kecurangan akademik mahasiswa Fakultas Ekonomi Universitas Madura sehingga hipotesis 3 (H3) diterima. Penelitian ini sejalan dengan Penelitian ini sejalan dengan Muhammad Hadi Santoso (2014) yang menyebutkan bahwa terdapat pengaruh signifikan kesempatan berbuat kecurangan terhadap perilaku kecurangan akademik.

Hasil penelitian ini sejalan dengan teori yang dikemukakan oleh Albrecht, dkk (2012:37) bahwa semakin luas kesempatan yang ada maka semakin besar peluang untuk sesorang melakukan sesuatu. Mahasiswa yang berada dalam kelas dan yang memiliki kesempatan yang luas maka mahasiswa tersebut akan cenderung merasa lebih bebas untuk melakukan kecurangan akademik. Sebagai contoh ketika pengawas ujian dalam kelas tidak mengawasi dengan baik mahasiswa akan merasa mempunyai kesempatan yang luas untuk melakukan kecurangan akademik.

\section{Pengaruh Rasionalisasi Berbuat Kecurangan terhadap Kecurangan Akademik}

Menurut Tuanakotta (2010: 205) Rationalization (rasionalisasi) yaitu mencari pembenaran sebelum melakukan kejahatan, bukan sesudahnya. Rasionalisasi diperlukan untuk melawan hukum demi mempertahankan jati diri pelaku kecurangan. Sedangkan menurut Albrecht, dkk., (2012: 49) berpendapat bahwa rasionalisasi merupakan pembenaran diri atau alasan yang salah untuk suatu perilaku yang salah. Jadi, rasionalisasi berbuat kecurangan akademik merupakan suatu keadaan yang menjadikan perilaku kecurangan akademik adalah perbuatan salah menjadi benar dengan cara memberi alasan yang masuk akal.

Uji parsial (t) pada hasil penelitian menunjukkan terdapat pengaruh positif signifikan rasionalisasi berbuat kecurangan terhadap kecurangan akademik mahasiswa Fakultas Ekonomi Universitas Madura sehingga hipotesis $4(\mathrm{H} 4)$ diterima. Dari analisis data dalam penelitian ini dapat disimpulkan bahwa ada pengaruh positif rasionalisasi berbuat 
kecurangan terhadap kecurangan akademik. Hal ini menunjukkan, jika rasionalisasi kecurangan akademik tinggi maka kecurangan akademik mahasiswa juga akan tinggi. Selain itu, hasil analisis deskriptif diperoleh hasil rata-rata rasionalisasi berbuat kecurangan dalam kategori cukup tinggi.

Hasil penelitian ini menunjukkan fakta bahwa rasionalisasi berbuat kecurangan terhadap kecurangan akademik mahasiswa tergolong rendah yaitu 9,5\%. Hal ini terjadi dikarenakan masih terdapat faktor-faktor lain yang mempengaruhi kecurangan akademik pada mahasiswa Fakultas Ekonomi Universitas Madura.

Rasionalisasi berbuat kecurangan adalah suatu keadaan mencari pembenaran sebelum melakukan kecurangan akademik untuk melawan hukum dan mempertahankan jati diri pelaku kecurangan akademik. Rasionalisasi ini tidak hanya mendorong mahasiswa untuk melakukan kecurangan, namun rasionalisasi juga bisa membuat mahasiswa menjadi orang yang tidak memiliki rasa bersalah. Hal itu dikarenakan pada diri mahasiswa tindakan kecurangan sudah dianggap sebagai sesuatu yang wajar dilakukan.

Hasil penelitian ini sejalan dengan Penelitian ini sejalan dengan penelitian Muhammad Hadi Santoso (2014) yang menyebutkan bahwa terdapat pengaruh signifikan raasionalisasi berbuat kecurangan terhadap kecurangan akademik. Penelitian ini juga sejalan dengan teori Fraud Triangle bahwa terdapat tiga elemen yang mempengaruhi kecurangan, dan salah satu dari elemen tersebut adalah rasionalisasi berbuat kecurangan

\section{REKOMENDASI DAN KEBIJAKAN}

Berdasarkan hasil analisis dan pembahasan yang telah diuraikan pada bab sebelumnya, maka dapat diperoleh rekmendasi dan kebijakan sebagai berikut: 1). Tekanan akademik, kesemapatan berbuat kecurangan, dan rasionalisasi berbuat kecurangan secara simultan berpengaruh positif signifikan terhadap kualitas mahasiswa Fakultas Ekonomi Universitas Madura, karena terdapat kesesuaian dengan teori fraud triangle penyebab terjadinya kecurangan pada proses kademik. 2) Tekanan akademik berpengaruh positif signifikan terhadap kualitas mahasiswa Fakultas Ekonomi Universitas Madura, karena tekanan akademik berpengaruh terhadap tinggi rendahnya perilaku kecurangan. 3) Kesempatan berbuat kecurangan berpengaruh positif signifikan terhadap kualitas mahasiswa Fakultas Ekonomi Universitas Madura, karena semakin luas kesempatan yang ada maka semakin besar peluang untuk melakukan sesuatu. 4) Rasionalisasi berbuat kecurangan berpengaruh positif signifikan terhadap kualitas mahasiswa Fakultas Ekonomi Universitas Madura, karena suatu keadaan mencari pembenaran sebelum melakukan kecurangan akademik untuk melawan hukum dan mempertahankan jati diri pelaku kecurangan akademik.

\section{Kebijakan}

Berdasarkan uraian pembahasan dan kesimpulan yang telah didapatkan, maka berikut ini adalah saran yang bisa peneliti sampaikan: 1. Bagi peneliti selanjutnya, diharapkan bisa memperluas ruang lingkup objek tidak hanya bagi mahasiswa Akuntansi Fakultas Ekonomi Universitas Madura. Peneliti selanjutnya bisa meneliti pada mahasiswa Universitas lainnya dan bahkan bagi mahasiswa fakultas lainnya serta pada tingkat pendidikan, dari tingkat SD, SMP, SMA dan bagi perusahaan dari segi kinerja karyawan dan penjualan produk. 2. Peneliti selanjutnya bisa menggunakan variabel selain yang telah dipakai. Seperti variabel yang ada pada teori fraud triangle, dan kualitas mahasiswa dari segi proses akademik. 


\section{DAFTAR PUSTAKA}

Apriani Nidya, Edy Sujana, Gede Emi Sulindawati, 2017. Pengaruh Pressure, Opportunity, Dan Rationalization Terhadap Perilaku Kecurangan akademik (Studi Empiris: Mahasiswa Akuntansi Program S1 UniversitasPendidikan Ganesha; Jurnal Akuntansi Program S1, Vol.7 No.1 Tahun 2017.

Albrecht, 2012. Fraud Examination, penerbit Cengage Learning Asia.

Anwar. Kualitas Soft Skill Mahasiswa, 2014. Diakses: 21 Mei 2019. http://kbbi.web.id/mahasiswa/2014/05/28

Dwi Pamungkas Desiana, 2015.Pengaruh Faktor-Faktor Dalam Dimensi Fraud Triangle Terhadap Perilaku Kecurangan Akademik SiswaKelas XI Akuntansi SMK Negeri 1 Tempel.

Fuadi Maksum, 2016. Determinan Kecurangan Akademik Pada Mahasiswa Fakultas Ekonomi Universitas Negeri Semarang Dengan Konsep Fraud Triangle.

Faisal Dwi Kusuma Muhammad, 2018.Faktor-Faktor Yang Mempengaruhi MahasiswaMelakukan Tindakan Kecurangan Akademik Dengan Perspektif Fraud Diamond Dan Religiusitas (Studi Pada Mahasiswa Akuntansi Universitas Islam Indonesia).

Hadi Santoso Muhammad, 2012. Analisis Perilaku Kecurangan Akademik Pada Mahasiswa Akuntansi Dengan Menggunakan Konsep Fraud Triangle.

Ikhsan Arfan, SE, M.Si, Januari 2008. Metode Penelitian Akuntansi Keperilakuan ; Edisi Pertama.

Sugiyono,2012. Metode Penelitian Administrasi; Penerbit Alfabeta, Bandung.

Sugiyono, Maret 2016. Metode Penelitian Administrasi; Cetakan ke-23.

Sugiyono. 2018. Metode Penelitian Kuantitatif Kualitatif dan R\&D. Alfabeta. Bandung.

Supriyono,2013. Metode Penelitian Bisnis; Penerbit Alfabeta, Bandung.

Tuanakotta, Theodorus M, 2010. Akuntansi Forensik dan Audit Investigatif, penerbit Salemba Empat.

Tjahjono Subagio, SE, CFE, CIA, CISA, Josua Tarigan, SE, MBA, CFP, CMA, CSRS, Dr.H. Budi Untung , SH, CN, MM, Jap Efendi, Phd, Yohana Hardjanti, SE, CMA, AK, April 2013. Business Crime and Ethics.

Zimbelman Mark F, Conan C. Albrecht, W. Steve Albrecht, Chad O. Albrecht,2014.Akuntansi Forensik,Edisi ke-4. 